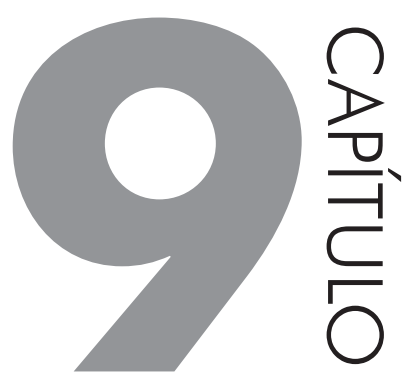

\title{
PADRÕES DE CONCORDÂNCIA VERBAL DE TERCEIRA PESSOA PLURAL NO PORTUGUÊS DE SÃO TOMÉ E NO PORTUGUÊS DE MOÇAMBIQUE
}

\section{KAREN CRISTINA DA SILVA PISSURNO}

\section{INTRODUÇÃO}

Os estudos sociolinguísticos sobre a concordância verbal, iniciados por volta de 1970 nas amostras brasileiras, demonstram uma variação muito produtiva em relação ao uso das regras de marcação plural no Português do Brasil (PB), especialmente por conta de fatores extralinguísticos, como os relativos a elementos socioeconômicos, à escolaridade dos indivíduos ou, ainda, às características de suas comunidades de fala, sobretudo em relação a seu perfil, mais rural ou mais urbano. No que se refere às variedades africanas, entretanto, não se dispõe de descrições científicas suficientes, sobretudo ancoradas em abordagens quantitativas de dados, que constatem o estatuto da regra de concordância.

Acredita-se, portanto, na relevância atribuída às investigações sociolinguísticas das variedades de Português do continente africano que considerem a marcação de número, não somente por contribuírem para a descrição das diferentes normas da Língua Portuguesa, mas, especialmente, por abordarem a questão da intensa situação de contato linguístico presente nessas sociedades. Tais investigações podem colocar em relevo especificidades que são encontradas em contexto multilíngue e que tendem, invariavelmente, a distanciar, de certa maneira, as 
variedades africanas do seu suposto "modelo" de aquisição - o Português Europeu (PE) -, segundo estudos que revelam a alta preferência dessa variedade pelo uso das marcas de plural, independentemente de estrato social ou escolaridade.

Além disso, o aprofundamento das questões relacionadas ao contato linguístico pode trazer luzes, em última instância, ao produtivo debate quanto às interpretações sobre as origens e as especificidades do PB. De acordo com Lucchesi; Baxter; Silva (2009), teria ocorrido na formação do Português em terras brasileiras o que se pode definir como um caso de transmissão linguística irregular, segundo o qual os modelos linguísticos adquiridos pelos novos falantes de Português indicariam o uso de adaptações representativas do contato entre línguas, dentre as quais é possível destacar a simplificação morfológica - o que se correlacionaria à marcação de pluralidade. Tendo em vista o cenário descrito pelos autores, entende-se que as características de formação das variedades africanas em meio ao multilinguismo - que, guardadas suas proporções, se assemelham à formação do $\mathrm{PB}$ - possam colaborar, considerando o Princípio do Uniformitarismo, para a explicação dos processos que originaram a variedade brasileira do Português.

Sendo assim, pretende-se considerar resultados de investigações sobre a concordância verbal em duas variedades africanas do Português, a de São Tomé e Príncipe (PST) e a de Moçambique (PM), a partir dos princípios da Teoria da Variação e Mudança (WEINREICH, LABOV, HERZOG, 1968; LABOV, 1972, 1994, 2003) e verificar se, nessas variedades, a concordância verbal constitui uma regra semicategórica ou variável, nos termos de Labov (2003). Assim, a partir da distribuição geral dos dados quanto ao fenômeno em questão e da investigação das motivações linguísticas e extralinguísticas que (des-)favorecem a realização da marca de terceira pessoa do plural nas formas verbais, constata-se o tipo de regra presente em cada variedade do Português. Sobre os fatores extralinguísticos, considera-se de extrema importância, devido ao contexto multilíngue das regiões examinadas, observar a influência do uso simultâneo de outra(s) língua(s) dominada(s) pelos falantes de Português sobre os resultados obtidos.

Para tanto, o presente capítulo sintetiza, na Seção 2, as informações a que se teve acesso quanto aos padrões de concordância nas referidas variedades africanas e suas diferenças em relação ao PE. Na Seção 3, apresentam-se os objetivos de duas pesquisas da concordância verbal - uma com dados do PM (PISSURNO, 2017) e a outra, do PST (VIEIRA; SILVA, 2017) - no âmbito do Projeto Estudo comparado dos padrões de concordância em variedades africanas, brasileiras e europeias do Português, além dos procedimentos metodológicos utilizados para a sua consecução. Em seguida, nas Seções 4 e 5, os resultados dos referidos estudos são apresentados, para que, na Seção 6, seja feita uma breve comparação entre os índices alcançados. Por fim, são tecidas, na Seção 7, as considerações finais. 


\section{O PE E A CONCORDÂNCIA VERBAL NAS VARIEDADES AFRICANAS DO PORTUGUÊS}

Tendo em vista o processo de colonização em terras africanas, o PE tem atuado como norma de referência e modelo de aquisição no contexto de formação das variedades africanas da Língua Portuguesa, conforme propõe Pissurno (2017):

O Português Europeu é a variedade tida como modelo de formação para todas as outras variedades do Português, por ter-se configurado historicamente como língua de maior prestígio, representante do colonizador e das oportunidades de ascensão social. Por representar a idealização do que seria o padrão correto a ser seguido, o PE é, muitas vezes, considerado como uma língua em que a variação é inexpressiva, especialmente no que tange ao fenômeno da concordância verbal, porque sua ocorrência seria ínfima. (PISSURNO, 2017, p. 88)

Sendo assim, torna-se imprescindível o conhecimento dos padrões de concordância na variedade europeia do Português para a compreensão das semelhanças e diferenças entre ela e as novas variedades em formação ou já configuradas. Investigações variacionistas com dados do PE (VAREJÃO, 2006; MONGUILHOTT, 2009; GANDRA, 2009; VIEIRA, 2011; RUBIO, 2012; MONTE, 2012; VIEIRA; BAZENGA, 2013) constataram que, efetivamente, ocorre ampla preferência pela marcação de pluralidade no PE. Considerando a aplicação das regras de concordância no PE, verifica-se que os índices de marcação em verbos de $3^{\text {a }}$ pessoa plural variam entre $90 \%$ e $97 \%$ das ocorrências computadas - variação que, segundo Vieira; Bazenga (2013), é motivada pelas opções metodológicas de cada estudo quanto aos critérios relativos à coleta de dados. Na realidade, trata-se de uma regra semicategórica de concordância, ficando as ocorrências de não marcação restritas a contextos muito específicos, a saber: sujeito posposto ou não realizado, de referência inanimada ou, ainda, representado por pronome relativo que. Em termos extralinguísticos, destaca-se, ainda, que a variável escolaridade não impõe qualquer restrição sobre os resultados europeus, ao contrário do que acontece, ao que tudo indica, nas demais variedades.

Do perfil da variedade europeia, deriva que os padrões de concordância verificados figurem como modelo de aprendizagem do Português, a ser apresentado nos manuais (gramáticas e livros didáticos) das escolas africanas, de modo que todo tipo de desvio a esse padrão seja possivelmente considerado como estrutura a ser corrigida.

Em relação ao PM, não se teve acesso a trabalhos variacionistas sobre a marcação de plural em formas verbais com base em análises contrastivas do Portu- 
guês. Gonçalves (2015), tratando especificamente desse fenômeno morfossintático, verificou que até mesmo os trabalhos que se dedicaram à descrição de dados parecem ter uma preocupação sistemática em indicar qual é a maneira correta de realizar tais estruturas. Como afirma a autora:

A maior parte dos estudos sobre a CV em PM, num total de 8, foram realizados numa perspectiva descritiva e, em alguns casos, têm como horizonte intervenções didáticas, destinadas a promover a competência gramatical dos estudantes nesta área gramatical. Esta dimensão didática decorre do fato de que, em Moçambique, tal como acontece no Brasil, a não realização da regra de concordância verbal constitui "um traço de diferenciação social, de cunho estigmatizante” (Vieira, 2007, p. 85). Até ao momento presente, não foram realizados estudos quantitativos com o objetivo de descrever detalhadamente o padrão da concordância variável no SV. (GONÇALVES, 2015, p. 13)

Gonçalves (1997), no trabalho intitulado "Tipologia de erros do Português Oral de Maputo", teve por objetivo reunir dados da fala moçambicana que servissem como fonte para a descrição dessa variedade. Da observação desses dados, a autora relata alguns casos de ausência de marcas no verbo, especialmente em contextos de sujeito posposto. Por sua vez, António (2011), considerando textos escritos por universitários, apresenta 42 ocorrências sem marcas, principalmente quando os sujeitos são complexos, nulos ou pronomes relativos, para além da posposição do sujeito - o que sugere um quadro variável de concordância verbal no PM.

Nhongo (2005), Bavo (2011) e António (2011), além de apresentarem, basicamente, os mesmos contextos que mais favorecem a não marcação supracitados, listam as estratégias de ensino e aprendizagem de Língua Portuguesa em Moçambique, fornecendo, inclusive, exercícios a serem trabalhados para o melhor treinamento das regras de concordância em sala de aula. Já Justino (2015a) reforça os condicionamentos para a ausência de marcas encontrados em trabalhos anteriores e indica que o grau de escolaridade dos falantes moçambicanos, nesses contextos, não altera efetivamente os resultados quanto à concordância verbal, pois até mesmo os colaboradores com ensino superior mostram as mesmas tendências de não marcação de plural nos contextos de frases complexas e sujeitos pospostos.

Como se pode observar, a concordância verbal na variedade moçambicana é, de fato, uma área que gera conflitos em relação ao Português Europeu, já que os trabalhos supracitados apontam a existência de contextos que distanciam, em certa medida, o PM de seu suposto modelo. Essa constatação é confirmada no primeiro trabalho sociolinguístico quantitativo sobre a concordância verbal no 
Português moçambicano, realizado por Pissurno (2017), cujos resultados serão discutidos no âmbito do presente artigo (cf. Seção 4).

Considerando a variedade são-tomense do Português, algumas investigações sobre a concordância verbal já realizadas (FIGUEIREDO, 2009, 2010; VIEIRA, 2011; BRANDÃO; VIEIRA, 2012, VIEIRA; BAZENGA, 2013, VIEIRA; BRANDÃO, 2014) revelam tendências de que, embora haja ampla preferência pela marcação de plural, a aplicação das regras de concordância na variedade são-tomense pode ser considerada parcial. Observa-se, especialmente, que, resguardadas as diferenças entre os níveis de variação e os contextos em que ela ocorre, São Tomé parece assumir um comportamento de regra variável em contextos semelhantes aos que se verificam nas variedades brasileiras.

Em termos comparativos, Vieira; Brandão (2012b) propõem que os padrões de concordância verbal do PST permitem localizá-lo quanto a seu perfil entre o PB e o PE. Se, de um lado, o PST não alcança níveis de marcação tão altos ou semicategóricos quanto os da variedade europeia, não apresenta, de outro, uma gama tão variada de contextos desfavorecedores da marcação de número nem níveis tão baixos de variação quanto os do $\mathrm{PB}$, sobretudo em variedades urbanas populares.

\section{OBJETIVOS E PROCEDIMENTOS METODOLÓGICOS}

Os estudos das variedades africanas do Português apresentados no presente texto tomam por base os princípios da Teoria da variação e mudança (WEINREICH, LABOV, HERZOG, 1968). Seguindo tais princípios, as investigações descrevem - com base no instrumental estatístico fornecido pelo pacote de programas Goldvarb-X para a realização da análise multivariada dos dados - os fatores linguísticos e sociais relevantes ao condicionamento da marcação de plural em amostras de cada variedade.

Assim, tanto em referência a Moçambique quanto a São Tomé, os trabalhos tratam de todas as ocorrências com e sem marca verbal de terceira pessoa do plural e das restrições para o uso de cada variante. Os resultados relativos a Moçambique foram retirados da pesquisa de mestrado de Pissurno (2017), que considera 18 entrevistas sociolinguísticas realizadas no ano de 2016 na capital do país, Maputo. Já para São Tomé, relatam-se os resultados apresentados por Vieira; Silva (2017), em trabalho que reúne análises anteriores (cf., dentre outros, VIEIRA, 2011; VIEIRA; BRANDÃO, 2014; VIEIRA; BAZENGA, 2013, 2015) considerando $27^{1}$ inquéritos da variedade urbana do PST.

1 É importante salientar que, no caso de São Tomé, não foi possível considerar uma informante idosa de curso superior, porque a amostra VAPOR não apresenta qualquer gravação com esse 
Dessa forma, para as duas amostras em estudo, os indivíduos deveriam preencher os critérios estabelecidos em relação à idade (18-35 anos; 36-55 anos; acima de 56 anos), à escolaridade (ensino fundamental; ensino médio; ensino superior) e ao sexo (feminino; masculino).

Ressalte-se que, enquanto na amostra são-tomense todos os informantes se declaram falantes de Português como L1, embora não o empreguem com a mesma frequência nem na mesma variedade de interações sociais, na amostra moçambicana tal configuração não pôde ser mantida, devido ao caráter social bastante distinto constatado na comunidade em questão. Sendo assim, todos os informantes do PM são falantes de Língua Portuguesa, seja ela sua língua materna ou não. A esse respeito, cabe observar que Maputo, sendo a capital do país, recebe pessoas de diferentes origens, advindas de todas as províncias de Moçambique. Esse complexo quadro linguístico dificultou a seleção de informantes que tivessem somente o Português como sua língua materna, como explica Pissurno (2017):

Por conta disso, apesar de buscarmos inquirir pessoas nascidas e criadas na cidade de Maputo, muitas entrevistas, na verdade, contemplam indivíduos nascidos em outras províncias e/ou que têm pelo menos um membro de sua família, seja o pai, a mãe ou o cônjuge, que advém de alguma delas. Tal situação afeta diretamente a questão das línguas faladas por esses indivíduos, já que em cada província existe uma língua local que é mais utilizada, para além do Português, língua oficial do país. Em outras palavras, cada indivíduo que passa a morar na capital carrega consigo as influências de sua própria língua, além de adquirir, independentemente do nível de proficiência, ao menos uma das principais línguas faladas em Maputo, Changana e Rhonga $^{2}$. (PISSURNO, 2017, p. 101).

Além das variáveis referentes à constituição da amostra (idade, escolaridade, sexo), investigou-se, no caso das duas variedades africanas em questão, a influência do uso de outra(s) língua(s) pelo informante, para além do uso de Português, à luz do grupo de fatores idealizado por Brandão (2011). Esse grupo de fatores tem como

perfil, motivo pelo qual se chega ao total ímpar de informantes da amostra básica (17 ao invés de 18). Além dessas 17 entrevistas, o estudo de Vieira; Silva (2017) acrescenta os dados de uma amostra complementar, que possui 10 informantes jovens $(5$ meninos e 5 meninas, entre $10 \mathrm{e}$ 19 anos) ainda em fase escolar, totalizando 27 entrevistados. Ao que tudo indica, esse acréscimo pode permitir a observação do fenômeno da concordância em tempo aparente. A amostra de Moçambique, por outro lado, até o desenvolvimento da pesquisa de Pissurno (2017), dispunha somente dos informantes constituintes da amostra básica para a investigação.

2 Para maiores informações e detalhamento da distribuição das línguas autóctones em Maputo, cf. capítulo 3 do presente volume. 
base o depoimento dos próprios informantes que se declaram (i) no caso de São Tomé, como falantes apenas de Português; de Português e, eventualmente, de um crioulo; ou, ainda, de um crioulo em casa e o Português nas situações fora de casa; (ii) no caso de Moçambique, como falantes de Português, que apenas compreendem pouco das línguas locais; falantes fluentes de Português e de línguas locais; ou falantes que usam mais línguas locais do que o Português. Ainda na amostra moçambicana, controlou-se, também de acordo com os depoimentos dos indivíduos, o fato de considerarem-se falantes de Português como primeira língua (L1) ou segunda (L2).

Em relação aos fatores de natureza linguística, observou-se, na análise de ambas as variedades, a possível influência dos seguintes grupos: a posição do sujeito em relação ao verbo, a distância entre o núcleo do SN e o verbo, a presença de elementos intervenientes, a configuração morfossintática do sujeito, o número de constituintes do sujeito, o paralelismo no nível oracional (do sujeito para o verbo), a animacidade do referente sujeito, a saliência fônica, o tempo/modo verbal e a transitividade verbal.

A análise desses contextos de natureza linguística e extralinguística nas duas amostras serão apresentados a seguir. $\mathrm{Na}$ Seção 4, relatam-se os resultados da variedade moçambicana, enquanto a Seção 5 resume os índices já observados na variedade são-tomense. A Seção 6 trará uma breve comparação entre os resultados verificados nas duas amostras.

\section{A CONCORDÂNCIA VERBAL NO PM}

Pissurno (2017) atesta, como resultado geral, forte preferência pela concordância padrão na variedade moçambicana, revelando, consoante Labov (2003), o comportamento de uma regra semicategórica $(96,8 \%)$, na qual dos 2353 dados obtidos, 2278 deles são de concordância expressa, como se vê na tabela a seguir:

Tabela 1 Distribuição dos dados com e sem marca de P6 no PM

\begin{tabular}{|c|c|c|}
\hline CONCORDÂNCIA VERBAL DE P6 & OCORRÊNCIAS & PERCENTUAL \\
\hline Marcação de plural & $2278 / 2353$ & $96,8 \%$ \\
\hline Não marcação de plural & $75 / 2353$ & $3,2 \%$ \\
\hline
\end{tabular}

Fonte: Adaptado de Pissurno (2017: 155)

A análise estatística das ocorrências revelou a relevância efetiva de seis das variáveis decodificadas para os dados sem marcação plural; são elas: língua(s) dominada(s) pelo informante, posição do sujeito, saliência fônica, escolaridade, paralelismo clausal e tipo de verbo. Elas foram selecionadas exatamente nessa 
ordem; porém, para fins de organização do texto, serão apresentadas primeiramente as variáveis sociais e, em seguida, as linguísticas.

\subsection{Variáveis sociais}

\section{a) Lingua(s) dominada(s) pelo informante}

A primeira variável, selecionada pelo programa estatístico, demonstra-se um condicionamento extremamente relevante na variedade moçambicana, não somente por sua atuação em particular, mas também em relação a outras variáveis também investigadas (como a escolaridade e o uso de Português como L1 ou L2).

Como a Tabela 2 demonstra, o maior ou menor uso das línguas autóctones ao menos como declarado pelos próprios informantes - realmente afeta os índices de marcação de plural, como a hipótese previa, uma vez que a comparação entre os informantes que "falam mais línguas locais do que Português" e os demais confirma essa tendência. Desse modo, a baixa produtividade no uso da Língua Portuguesa nas interações sociais constitui um fator efetivamente desfavorecedor da concordância (apenas .11 para a concordância padrão).

Tabela 2 Aplicação da marca de P6 segundo a língua(s) dominada(s) pelo informante no PM

\begin{tabular}{|c|c|c|c|}
\hline USO DAS LínGUAS & OCORRÊNCIAS & PERCENTUAL & PESO RELATIVO \\
\hline $\begin{array}{c}\text { Só fala Português ou apenas compreende } \\
\text { línguas locais }\end{array}$ & $796 / 820$ & $97,1 \%$ & .49 \\
\hline $\begin{array}{c}\text { Fala, fluentemente, Português e línguas } \\
\text { locais (em determinados contextos) }\end{array}$ & $1448 / 1487$ & $97,4 \%$ & .53 \\
\hline Fala mais línguas locais do que Português & $32 / 44$ & $72,7 \%$ & .11 \\
\hline
\end{tabular}

Fonte: Adaptado de Pissurno (2017: 156)

Por outro lado, observe-se que os fatores "só fala Português e/ou apenas compreende (um pouco) as línguas locais" e "fala fluentemente línguas locais e Português" indicam comportamento bastante semelhante (apenas 4 pontos relativos de diferença), revelando uma polarização dos resultados em relação à concordância, como explica Pissurno (2017):

De um lado, observam-se os informantes que falam apenas Português (ou que podem ser considerados bilíngues passivos) juntamente com os falantes bilíngues, mostrando tendências de favorecimento à concordância verbal, ainda que seja possível notar oscilação no uso das variantes das duas categorias de falantes. De outro lado, verifica-se o favorecimento à não concor- 
dância por parte apenas daquele que tem maior contato com as línguas locais do que com o Português. (PISSURNO, 2017, p. 157)

Em poucas palavras, pode-se dizer que o maior contato somente com o Português não parece ser uma condição para altos índices de marcação (.49 e .53, respectivamente), mas é, sem dúvida, um fator que distancia, em cerca de 40 pontos, esses falantes daqueles que têm maior contato com as línguas autóctones.

É válido ressaltar que, a princípio, a hipótese previa um comportamento mais escalar, demonstrando que quanto maior fosse o uso de Português, maiores seriam os índices de marcação de número. No entanto, constatou-se que o cenário de multilinguismo propicia um quadro mais complexo e um pouco diferente daquele que era esperado, especialmente porque, ao que tudo indica, ter o Português como L1 e alta escolaridade não significa, necessariamente, um domínio pleno do padrão esperado - o PE. Pissurno (2017) resume a situação:

Considera-se, nesse caso, especialmente o primeiro grupo de falantes, que contém indivíduos que afirmam "compreender línguas locais", fato que, de acordo com Romaine (1995), já os classifica como bilíngues passivos, suscetíveis aos mesmos fenômenos variáveis de qualquer outro falante. [...] Da mesma forma, no que se refere ao fato de os indivíduos do segundo grupo falarem fluentemente línguas locais e Português, é possível que haja a confluência de muitos falantes bilíngues, aqueles que adquiriram as línguas ao mesmo tempo, desde crianças, independentemente de seu grau de escolaridade. Nesse caso, a aquisição simultânea possibilitaria um nível de proficiência muito similar nessas línguas, o que poderia causar oscilação em sua fala e, ao mesmo tempo, permitir que a aquisição das regras da Língua Portuguesa seja mais natural, resultando no leve favorecimento de uso das regras padrão. (PISSURNO, 2017, p. 157-158)

Considerando, portanto, que, em sociedades multilíngues como a moçambicana, o bilinguismo é praticamente uma regra, independentemente do nível de proficiência que o sujeito tenha nesta ou naquela língua, entende-se que monitorar a relação destes falantes com o seu conhecimento de Português como língua materna (L1) ou como segunda língua (L2) é extremamente relevante.

Contudo, vale ressaltar que até mesmo definir o estatuto da língua que usam se L1 ou L2 - constitui uma tarefa árdua para esses indivíduos. Assim, de acordo com a proposta de Romaine (1995), acredita-se que a língua que o indivíduo indica como sendo a sua materna é aquela com a qual ele mais se identifica, em termos culturais, e não aquela que ele aprendeu primeiro. No caso de Moçambique, portanto, são identificados dois perfis distintos: de um lado, o grupo de informantes que defendem o uso exclusivo do Português, pois desejam ascensão social e melhores condições de vida e supõem que usar línguas autóctones pode atrasar seu desenvolvimento social; de outro, aqueles que acreditam no valor cultural que os idiomas nacionais 
carregam e que incentivam o uso desses nos ambientes de maior representatividade (igreja, em casa, com os amigos), creditando maior importância às línguas locais do que ao Português, que seria apenas mero instrumento de comunicação geral.

Em outras palavras, a relação do indivíduo com o Português como L1 ou L2 mostra-se um grupo de fatores relevante ao aprofundar os conhecimentos sobre a variedade moçambicana. Entretanto, sua correlação com o domínio de outras línguas, como dito no início desta seção, representa um caráter bastante particular da variedade em questão, que precisa ser investigado. Em linhas gerais, Pissurno (2017) traça os resultados obtidos com a análise referente ao suposto uso que os entrevistados fazem da Língua Portuguesa:

Dentre os 18 informantes da amostra, os 11 que se declaram falantes de Português como língua materna são, especialmente, nascidos e criados em Maputo, onde a Língua Portuguesa já é majoritária e o incentivo a seu uso é extremamente valorizado. Além disso, estes também são representados por aqueles moçambicanos que tiveram maior convivência com portugueses, seja na família ou por ter passado algum tempo em Portugal e, com toda certeza, aqueles com níveis mais altos de escolaridade. [...] Considerando, de outro lado, os sete informantes da amostra que se declaram falantes de Português L2, vemos que, para muitos deles, aprender a Língua Portuguesa foi quase uma "obrigação", algo que lhes permitiria frequentar a escola. (PISSURNO, 2017, p. 160)

A partir das considerações feitas pela autora, reflete-se sobre a atuação de uma segunda variável que envolve a questão do domínio das línguas, o grau de instrução do indivíduo. Ao que parece, ter Português como língua materna é condição para promover acesso ao conhecimento e a níveis mais elevados de escolaridade, mesmo que o domínio simultâneo de línguas autóctones influencie, em alguma medida, a variedade de Português que o indivíduo usa, porque, nesse contexto de bilinguismo, a variação em relação ao padrão tende a ser inevitável.

\section{b) Escolaridade}

Como é possível verificar na Tabela 3, o nível de escolaridade mostra-se, igualmente, um condicionamento extralinguístico bastante relevante para a marcação de número no PM. Como a hipótese indicava, confirmou-se uma escalaridade nos índices de aplicação da regra, proporcional ao aumento dos anos em que o indivíduo esteve em contato com a educação formal.

Os informantes de ensino fundamental destoam dos demais no que se refere ao expressivo desfavorecimento da concordância verbal (.29), enquanto aqueles que possuem média ou alta escolaridade apresentam índices $(.58$ e .65 , respectivamente) em favor da marcação. Observe-se, por outro lado, que os resultados revelam somente " 16 ocorrências de ausência de marca de número no ensino 
médio e 13 no ensino superior, o que nos mostra que, mesmo sendo ínfima a quantidade de "desvios", é válido reparar a diferença de apenas três dados entre esses dois níveis de instrução escolar” (PISSURNO, 2016, p. 164). De forma geral, verifica-se que ambos os níveis de escolaridade apresentam percentuais próximos aos $98 \%$ de marcação padrão, confirmando que a diferença de comportamento entre os dois é bem pequena.

Tabela 3 Aplicação da marca de P6 segundo a escolaridade no PM

\begin{tabular}{|c|c|c|c|}
\hline ESCOLARIDADE & OCORRÊNCIAS & PERCENTUAL & PESO RELATIVO \\
\hline Ensino Fundamental & $719 / 765$ & $94 \%$ & .29 \\
\hline Ensino Médio & $828 / 844$ & $98,1 \%$ & .58 \\
\hline Ensino Superior & $729 / 742$ & $98,2 \%$ & .65 \\
\hline
\end{tabular}

Fonte: Adaptado de Pissurno (2017: 163)

Ao que tudo indica, os resultados observados a partir da análise da variável escolaridade parecem estar diretamente interligados ao maior ou menor uso de outras línguas, além do Português, em Moçambique. Na realidade, nessa variedade, ter mais anos de escolaridade significa maior contato com a Língua Portuguesa, já que é a língua majoritária nas escolas; assim, proporcionalmente, os informantes com menos anos de educação formal são aqueles que supostamente recebem maiores influências das outras línguas faladas na comunidade.

Com o intuito de compreender melhor essa interação entre a escolaridade e o uso de línguas, Pissurno (2017) realizou um cruzamento entre as duas variáveis, de modo a aferir como o contato entre línguas pode afetar tanto os informantes que se declaram falantes de Português como L1, quanto aqueles que se afirmam bilíngues. A Figura 1 apresenta os resultados de tal cruzamento:

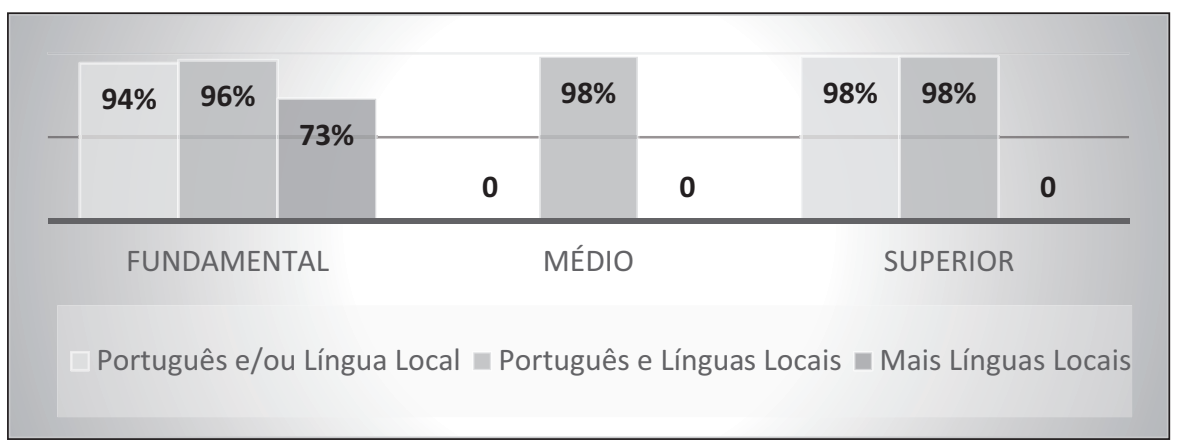

Figura 1 Cruzamento de dados com marca de P6: língua(s) dominada(s) pelo informantex escolaridade no PM 
Como a Figura 1 revela, apenas o contexto do ensino fundamental em Moçambique apresenta resultados para os três fatores estabelecidos para o uso de línguas na região. Em outras palavras, somente esse grupo de indivíduos com menor escolaridade declara usar as línguas locais com maior ou menor proficiência e produtividade. Contudo, é importante destacar que o único índice abaixo dos $90 \%$ de concordância padrão é o encontrado para o fator "fala mais línguas locais do que Português". Esse baixo percentual de realização da marca de plural, em apenas $73 \%$ das ocorrências, é referente à fala do único informante de toda a amostra que se declarou como tal tipo de falante. Em poucas palavras, trata-se de um indivíduo bastante diferente dos outros perfis entrevistados, por conta de sua baixa escolaridade e suas notáveis dificuldades com a Língua Portuguesa de forma geral ${ }^{3}$.

Em relação ao ensino médio, constata-se ser esse o único fator que apresenta apenas falantes bilíngues. Por fim, no ensino superior, os falantes são ora falantes apenas de Português, ora de Português e de línguas locais simultaneamente, porém ambos os fatores indicam elevada preferência pela concordância (98\%).

Do exposto, reforça-se a hipótese de que ter contato com línguas autóctones influencia, de fato, a marcação de pluralidade no PM, representando as maiores tendências à ausência de marcas quanto maior for o uso desses idiomas. Além disso, como aponta Pissurno (2017):

Observa-se que ser bilíngue é uma realidade muito presente nessa amostra, independentemente do nível de escolaridade. Com isso, nota-se que, para a maioria dos informantes aqui analisados, o Português foi adquirido com algum tipo de influência das línguas locais, mesmo que alguns afirmem o contrário. Às vezes, o simples fato de alguém da família ser fluente em idiomas locais já pode exercer algum tipo de influência no Português falado por eles. (PISSURNO, 2017, p. 165)

Por fim, destaca-se, ainda, que, de acordo com Pissurno (2017), sendo a escolaridade uma variável tão importante para a configuração da regra de concordância verbal no Português de Moçambique, é válido considerar que os professores de Língua Portuguesa passam pelas mesmas interferências linguísticas que

3 Como esclarece Pissurno (2017, p. 158): "Esse informante (PMOC1H) possui apenas a 4 a classe do ensino fundamental, ou seja, seu contato com a Língua Portuguesa foi, de fato, muito menor do que o de alguns outros informantes pertencentes aos outros grupos. Seus resultados referentes à marcação de concordância chegam aos $73 \%$ (limiar referente à variação) e ele apresenta dificuldades em outras áreas relacionadas ao processamento do mecanismo de concordância em geral, como a de gênero e a nominal, por exemplo, que ele utiliza pouquíssimas vezes de acordo com as regras do Português padrão ao longo de sua entrevista.” 
seus alunos e, consequentemente, transmitem regras de um Português (seja como L2 ou como uma L1 com influência, inerente, das línguas autóctones) que podem não refletir totalmente aquelas que são consideradas padrão no Português Europeu, dando margem a contextos variáveis. Assim, reforça-se a existência de uma conexão muito forte entre a escolaridade e o uso de Português nessa sociedade. Como a Figura 2 revela, "não existe qualquer informante de ensino superior que seja falante de Português como L2" e, ao mesmo tempo, o menor índice de marcação de plural (91\%) "é observado exatamente nos indivíduos de ensino fundamental que não têm o Português como sua língua materna” (PISSURNO, 2017, p. 166.)

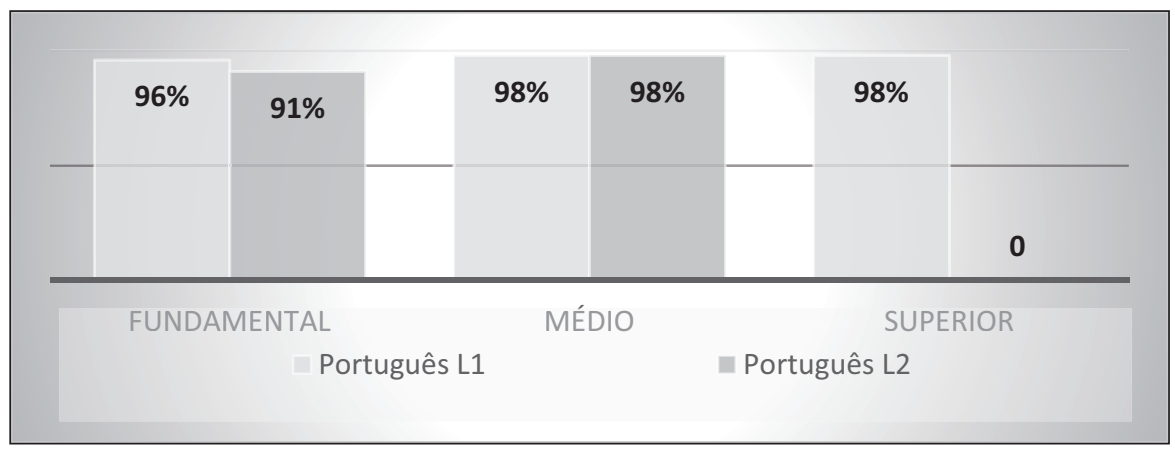

Figura 2 Cruzamento de dados com marca P6: língua maternax escolaridade no PM

Fonte: Adaptado de Pissurno (2017: 166)

Em suma, conclui-se que a escolaridade e as línguas dominadas pelos indivíduos dessa amostra são, sem dúvida, características extremamente relevantes para o entendimento da variedade moçambicana de Português. No entanto, elas devem ser analisadas em relação a outras variáveis extralinguísticas que, apesar de não serem estaticamente relevantes, demonstram a atuação de vários fatores particulares à realidade social da variedade em questão. Devido à delimitação do presente capítulo, optou-se por apresentar apenas a influência do Português como L1 ou L2 nos dados ${ }^{4}$ obtidos.

\subsection{Variáveis linguísticas}

a) Posição do sujeito

Conforme a Tabela 4, pode-se notar o efeito inegável da posição do sujeito no condicionamento das marcas de número no PM, já que nos contextos de sujei-

4 Pissurno (2017) ainda levanta questionamentos relacionados a outras variáveis como a faixa etária e as características individuais dos informantes. 
to posposto a tendência é a de desfavorecimento da concordância padrão (.17), enquanto o sujeito anteposto favorece o uso das marcas (.58).

Tabela 4 Aplicação da marca de P6 segundo a posição do sujeito no PM

\begin{tabular}{|c|c|c|c|}
\hline POSIçÃo dO SUJEITO & OCORRÊNCIAS & PERCENTUAL & PESO RELATIVO \\
\hline Sujeito anteposto & $1196 / 1228$ & $97,4 \%$ & .58 \\
\hline Sujeito posposto & $202 / 223$ & $90,6 \%$ & .17 \\
\hline
\end{tabular}

Fonte: Adaptado de Pissurno (2017: 175)

Seguem abaixo alguns exemplos encontrados na amostra analisada, que confirmam a tendência de não haver marcas quando o sujeito aparece depois do verbo (exemplos 1 e 2), diferentemente do que ocorre quando o sujeito se encontra antes da forma verbal (exemplos 3 e 4):

(1) tinha velhos colono ainda... saiu os colono consolidar a vida (PMOC1H)

(2) às vezes vinha dois três... conforme eles iam crescendo não é... (PMOC3M)

(3) as cidades começam a ficar um pouco mais aceleradas e começam a: surgir de certa maneira neste momento de certa maneira focos né criminalidade $(\mathrm{PMOB} 3 \mathrm{H})$

(4) eles fazem essas coisas todas na praia (PMOA2H)

Ainda sobre a influência do sujeito sobre os resultados encontrados, é importante destacar a atuação de uma configuração morfossintática específica desse constituinte, quando este conta com a presença de pronome relativo. Dos $32 \mathrm{da}-$ dos sem marca de número em contexto de sujeito anteposto encontrados, 10 eram de sujeito representado pelo relativo que. Esse comportamento sugere que a presença do pronome relativo exerce influência sobre a marcação de pluralidade verbal, comportando-se, assim, como contexto desfavorecedor da concordância, conforme se pode atestar nos exemplos a seguir:

(5) para nossas criança elas que vai fazer furo / futuro melhore... (PMOC1H)

(6) ah: é normal colegas meus que tá no outro no outro semestre da faculdade escreverem muito mal português... (PMOA3H)

(7) conflitos armados e: : guerra que assola lá na zona centro... (PMOB1H)

(8) casamentos daqui não dura até pior que os que casa oficialmente é normal uma pessoa casar este ano e próximo ano já divorciou (PMOB1M)

A respeito dos exemplos destacados, Pissurno (2017) faz duas observações relevantes sobre esse condicionamento: 
(i) apenas dois desses dados (5 e 6) não são construídos com verbos representativos do grau 1 de saliência, ou seja, a maioria dos casos de ausência de marcas de plural em sujeitos representados pelo pronome que são, coincidentemente, verbos de baixa saliência fônica, que por si só, já são favorecedores da não marcação.

(ii) apenas um foi produzido por um informante que não fosse do ensino fundamental [...] mesmo que seja apenas um exemplo do ensino superior, pode-se ver que o pronome relativo pode atuar, ainda que muito discretamente, no conjunto de fatores, para a ausência de concordância. No caso desse informante, essa foi a única ocorrência de ausência de marca de número no seu discurso (6). (PISSURNO, 2017, p. 178)

\section{b) Saliência fônica}

O comportamento da variável saliência fônica (Tabela 5) confirma as hipóteses previstas de que os graus (1 e 2) de menor distanciação fônica entre as formas de singular e plural desfavoreceriam a concordância (.38 e .37, respectivamente), enquanto os graus $(3,4$ e 5$)$ de maior saliência favoreceriam a presença das marcas.

Tabela 5 Distribuição dos dados com marca de P6 segundo saliência fônica no PM

\begin{tabular}{|c|c|c|c|}
\hline SALIÊNCIA FÔNICA & OCORRÊNCIAS & PERCENTUAL & PESO RELATIVO \\
\hline Grau 1 - come(m) / fala(m) & $1268 / 1319$ & $96,1 \%$ & .38 \\
\hline Grau 2 - faz/fazem & $196 / 201$ & $97,5 \%$ & .54 \\
\hline Grau 3 - dá/dão & $331 / 339$ & $97,6 \%$ & .56 \\
\hline Grau 4 - comeu/comeram & $145 / 237$ & $96,2 \%$ & .94 \\
\hline
\end{tabular}

Fonte: Adaptado de Pissurno (2017: 180)

Observe-se, ainda, que, enquanto os graus 3 e 4 demonstram comportamento similar quanto ao favorecimento da concordância padrão $(.54$ e .56 , respectivamente), no grau 5 a probabilidade de favorecer a marcação é altíssima (.94), o que corresponde a um subconjunto de dados, em que a ausência de marcas de número ocorreu em apenas dois dados. A seguir, apresenta-se um exemplo de verbo para cada um dos graus de saliência fônica estabelecido:

\section{Grau 1}

(9) que eles fica devendo em dinheiro quando às vezes nem tem dinheiro... (PMOB2H) 


\section{Grau 2}

(10) os mais antigos faz muita confusão na profissão polícia como é possível pagar e eles pronto não pegam a multa deixa seguir e vai andando (PMOC1M)

\section{Grau 3}

(11) porque já tem encontrado alguns professores que dão teste então dão teste em troca de favores (PMOA1M)

\section{Grau 4}

(12) algumas pessoas saíram ali e disseram que... nós não fomos atacados pelos homens da RENAMO (PMOA2H)

\section{Grau 5}

(13) mas algumas crianças são boas... tem um bom aproveitamento... comportam-se bem... (PMOC2M)

Cabe ressaltar que o comportamento do PM em relação à saliência fônica mostra o quanto essa variável é importante para a caracterização das variedades do Português, como já destacaram Vieira; Brandão (2014) ao afirmarem que PB e PE constituem sistemas opostos de concordância, porque a ausência da mesma é condicionada por fatores diferentes. Dentre esses fatores, as autoras destacam a saliência, variável relevante em amostras de variedades brasileiras, mas não na variedade europeia. Scherre; Naro (2006) corroboram esse argumento, quando apontam que a saliência não é significativa quando produzida por falantes altamente escolarizados. Dessa forma, Pissurno declara:

a preferência exclusiva pela variante padrão no PE acaba por apagar a atuação desse grupo de fatores, diferentemente do que ocorre no $\mathrm{PB}$, sobretudo nas variedades populares, e no PM, que aparentemente têm, em termos qualitativos (embora com padrões quantitativos bem diferentes), comportamento similar no fenômeno da concordância. (PISSURNO, 2017, p. 183)

Em poucas palavras, entende-se que os condicionamentos que afetam a concordância no PM, principalmente a escolaridade e a saliência fônica, indicam não obstante os diferentes índices gerais de não concordância - semelhanças relativas aos contextos de ausência de marca que ocorrem nas variedades brasileiras, distanciando, de certa forma, a variedade moçambicana, em termos qualitativos, de seu modelo europeu de aprendizagem.

\section{c) Paralelismo oracional}

A partir do princípio geral do paralelismo, de que marcas levam a marcas e zeros levam a zeros (SCHERRE; NARO, 1993), constata-se, nos dados da variedade em questão, a confirmação dessa hipótese. 
Como se vê na Tabela 6, dados em que o verbo é antecedido de um sintagma com marcas favorecem a concordância (.52), ao passo que os sintagmas sem marca acarretam a ausência da mesma nos verbos (.5 para a concordância padrão).

Tabela 6 Aplicação da marca de P6 segundo paralelismo clausal no PM

\begin{tabular}{|c|c|c|c|}
\hline PARALELISMO ORACIONAL & OCORRÊNCIAS & PERCENTUAL & PESO RELATIVO \\
\hline SN com marcas de plural & $1168 / 1194$ & $97,8 \%$ & .52 \\
\hline SN sem marcas de plural & $4 / 8$ & $50 \%$ & .5 \\
\hline SPrep marcado ou não & $27 / 29$ & $93,1 \%$ & .23 \\
\hline SN's coordenados & $9 / 11$ & $81,8 \%$ & .12 \\
\hline
\end{tabular}

Fonte: Adaptado de Pissurno (2017: 184)

Os exemplos a seguir confirmam os índices obtidos: enquanto no (14) a presença de marcas explícitas de plural no sintagma "as meninas" acarreta a marcação padrão do verbo "vivem", no (15) a ausência delas em "as mulher" gera o apagamento da marca também no verbo "deixa":

(14) as meninas vivem ali... vêm dos distritos... são meninas de famílias... muito carentes... (PMOC3M)

(15) porque as mulher daqui não deixa a possibilidade (PMOA1H)

Sobre a atuação dos outros contextos em relação ao desfavorecimento da concordância no PM, Pissurno (2017) esclarece:

o cancelamento das marcas de pluralidade, de fato, diminui à medida que os SN's sujeitos apresentam quaisquer marcas de número. Sendo assim, a tendência de não marcação nos contextos analisados obedeceria a seguinte ordem: SN sem marcas $>$ SN's coordenados $>$ SPrep marcado ou não $>$ SN com marcas. (PISSURNO, 2017, p. 185)

Assim, pode-se concluir que os resultados encontrados confirmam as tendências gerais sobre o paralelismo: a ausência de marcas formais no sujeito enunciado favorece a ausência de concordância padrão nos verbos que o seguem.

d) Tipo de verbo

Por fim, a última variável selecionada como relevante para o PM foi o tipo de verbo. Observem-se os resultados obtidos na Tabela 7, a seguir: 
Tabela 7 Aplicação de marca de P6 segundo tipo de verbo no PM

\begin{tabular}{|c|c|c|c|}
\hline TIPO DE VERBO & OCORRÊNCIAS & PERCENTUAL & PESO RELATIVO \\
\hline Inergativos e Inacusativos & $295 / 319$ & $92,5 \%$ & .37 \\
\hline Transitivos & $1549 / 1589$ & $97,5 \%$ & .56 \\
\hline Copulativos & $434 / 445$ & $97,5 \%$ & .40 \\
\hline
\end{tabular}

Fonte: Adaptado de Pissurno (2017: 186)

De acordo com esses resultados, verifica-se que os verbos transitivos são os favorecedores da marcação de plural (.56) na presente amostra. Por outro lado, os contextos desfavorecedores são os verbos inergativos/inacusativos (.37) - como no exemplo (16) - e os copulativos (.40), como no exemplo (17):

(16) então ainda existe muitos lobolos (PMOA1M)

(17) e os donos da casa também que já era velhinhos (PMOB2M)

Ao considerar a variável tipo de verbo, não se pode deixar de lembrar que existe uma correlação muito forte desse grupo de fatores com a posição do sujeito em questão, como apontam Scherre; Naro; Cardoso (2007). No referido trabalho sobre a amostra moçambicana, tal correlação foi confirmada ${ }^{5}$, tendo tido atuação mais forte a posição do sujeito em relação ao verbo. De acordo com os referidos autores, "independentemente do tipo de verbo, qualquer argumento ou sintagma à direita do verbo tende, relativamente, a diminuir as marcas de concordância explícita" (SCHERRE; NARO; CARDOSO, 2007, p. 312).

A posição do sujeito constitui, portanto, um condicionamento que se pode considerar "geral" da Língua Portuguesa, pois ocorre tanto nas variedades africanas quanto na brasileira e até mesmo na europeia, como demonstram Vieira; Bazenga (2013). As autoras ainda afirmam que esse grupo de fatores "altera padrões de concordância em línguas de perfis e genealogias muito diferentes", o que "faz supor que não se trate de efeito efetivamente variável nesse caso, mas de comportamento estrutural gramaticalmente diferenciado" (VIEIRA; BAZENGA, 2013, p. 55).

Em síntese, as tendências encontradas demonstram que favorecem a concordância no Português de Moçambique: (i) das variáveis extralinguísticas: níveis

5 No desenvolvimento das variáveis linguísticas na dissertação, Pissurno (2017) apresenta os cruzamentos realizados entre as variáveis para a confirmação de tais hipóteses. Além disso, a autora apresenta outros testes executados sobre as variáveis em debate, que não cabiam no escopo do presente capítulo. 
médio e superior de escolaridade e falantes com mais contato com Língua Portuguesa e/ou bilíngues; (ii) das variáveis linguísticas em relação ao sintagma nominal: os sujeitos em posição anterior ao verbo e com marcas explícitas de plural; (iii) e das linguísticas em relação ao sintagma verbal, os verbos transitivos e com maior grau de saliência fônica (graus 3, 4 e 5). Por outro lado, baixa escolaridade, maior contato exclusivo com línguas autóctones, sujeitos pospostos, sintagmas sem marcas de plural, verbos inergativos/inacusativos e copulativos, assim como aqueles com baixa saliência fônica entre as formas singular e plural são os contextos que desfavorecem as marcas de concordância na amostra em estudo.

Em poucas palavras, resume-se a situação de Moçambique nas considerações de Pissurno (2017):

[...] pode-se concluir que os 75 dados de não concordância coletados são bastante variados, não sendo de uma mesma natureza. Nesse sentido, fica viável uma abordagem contrastiva, não só dos índices quantitativos, mas também da natureza dos dados da concordância na variedade moçambicana do Português, em termos qualitativos, com os padrões descritos para o $\mathrm{PB}$ e o PE. Embora quantitativamente os dados do PM estejam mais próximos dos registrados para o $\mathrm{PE}$ (como uma regra semicategórica) do que para o PB (como uma regra variável), a natureza estrutural dessas ocorrências e o comportamento dos indivíduos, caracterizados em termos sociolinguísticos, ao que parece, aproximariam, qualitativamente, o PM do PB e não do PE. (PISSURNO, 2017, p. 195-196)

Resta saber se tal comportamento também ocorre em outras variedades africanas que sofrem influências semelhantes em relação ao multilinguismo. Na próxima seção, portanto, serão relatados os resultados da variedade de São Tomé.

\section{A CONCORDÂNCIA NO PST}

No âmbito do projeto Estudo comparado dos padrões de concordância em variedades africanas, brasileiras e europeias do Português, o Português de São Tomé e Príncipe vêm sendo examinado com o objetivo de verificar os traços específicos da variedade que permitam, não só sua caracterização, como também sua comparação com outras variedades de Português, especialmente em relação ao fenômeno da concordância nominal e verbal.

A partir de tais objetivos, Brandão; Vieira (2012), em uma investigação que considerava 22 informantes da amostra são-tomense (17 informantes da amostra básica e 5 informantes da amostra complementar de ensino médio e superior), já atestavam a forte preferência pela concordância verbal (93,1\% de marcação) nessa variedade. Por sua vez, Vieira; Bazenga (2013, 2015), em uma análise contras- 
tiva das variedades do Português, observaram o comportamento da amostra básica (17 informantes), relatando, igualmente, altos índices de favorecimento das marcas de número $(92,1 \%$ de concordância padrão). Assim, pode-se dizer que, de maneira geral, atua sobre essa variedade uma regra variável de concordância verbal.

Com base nesses trabalhos, Vieira; Silva (2017) examinaram, além das entrevistas da amostra básica, uma amostra complementar de 10 informantes jovens (10 a 19 anos), e encontraram 100 ocorrências com ausência de marcas de número dentre os 1053 dados obtidos. Dessa forma, obteve-se $90,5 \%$ de preferência pela concordância verbal padrão, conferindo, novamente, um estatuto de regra variável para o fenômeno na variedade em questão, semelhante aos resultados encontrados nos trabalhos supracitados.

Tabela 8 Distribuição dos dados com e sem marca de P6 no PST

\begin{tabular}{|c|c|c|}
\hline CONCORDÂNCIA VERBAL DE P6 & PERCENTUAL & OCORRÊNCIAS \\
\hline Marcação de plural & $90,5 \%$ & $953 / 1053$ \\
\hline Não marcação de plural & $9,5 \%$ & $100 / 1053$ \\
\hline
\end{tabular}

Fonte: Vieira; Silva (2017: 22)

As variáveis com comportamento relevante para o tratamento estatístico da amostra de dados são-tomenses foram ${ }^{6}$, nesta ordem, escolaridade, animacidade do referente sujeito, posição do sujeito, sexo e paralelismo clausal. Assim como se fez para a descrição dos resultados do PM, as variáveis sociais serão apresentadas antes das linguísticas.

\subsection{Variáveis sociais}

\section{a) Escolaridade}

Semelhantemente ao que ocorre em Moçambique, em São Tomé os informantes de ensino fundamental mostram maior tendência ao desfavorecimento da

6 Destaca-se que, em Brandão; Vieira (2012), além das variáveis destacadas como relevantes por Vieira; Silva (2017), as autoras também obtiveram seleção estatística das variáveis faixa etária e saliência fônica na amostra que analisaram. Por sua vez, Vieira; Bazenga (2015) relacionam como variáveis significativas para a amostra o paralelismo, a posição do sujeito, a escolaridade, o sexo e o traço semântico do sujeito. Portanto, observa-se que, apesar de apresentarem algumas diferenças, nas três investigações há semelhanças quanto ao comportamento das variáveis escolaridade, sexo e posição do sujeito, como condicionadores do fenômeno. 
concordância verbal (.25), enquanto os que possuem ensino superior apresentam índice elevado de preferência pelas marcas de número (.82). Os informantes de ensino médio apresentam um comportamento intermediário em relação à marcação de pluralidade (.48).

Tabela 9 Aplicação da marca de P6 segundo a escolaridade no PST

\begin{tabular}{|c|c|c|c|}
\hline ESCOLARIDADE & OCORRÊNCIAS & PERCENTUAL & PESO RELATIVO \\
\hline Fundamental & $290 / 348$ & $83 \%$ & .25 \\
\hline Médio & $371 / 406$ & $91 \%$ & .48 \\
\hline Superior & $292 / 299$ & $98 \%$ & .82 \\
\hline
\end{tabular}

Fonte: Vieira; Silva (2017: 22)

Em termos percentuais, observa-se a mesma escalaridade de marcação que as variedades moçambicana e brasileira, revelando que os índices mais altos de marcação de número se realizam na fala dos informantes que possuem mais anos de educação formal. Por outro lado, menos anos de escolaridade registram menores índices de marcação de plural, o que indica não só menor domínio das regras do Português "padrão", como também maior contato com as línguas crioulas faladas no país.

A partir de tal constatação, Vieira; Silva (2017) propõem um cruzamento entre as duas variáveis, resumido na Figura 3, que segue:

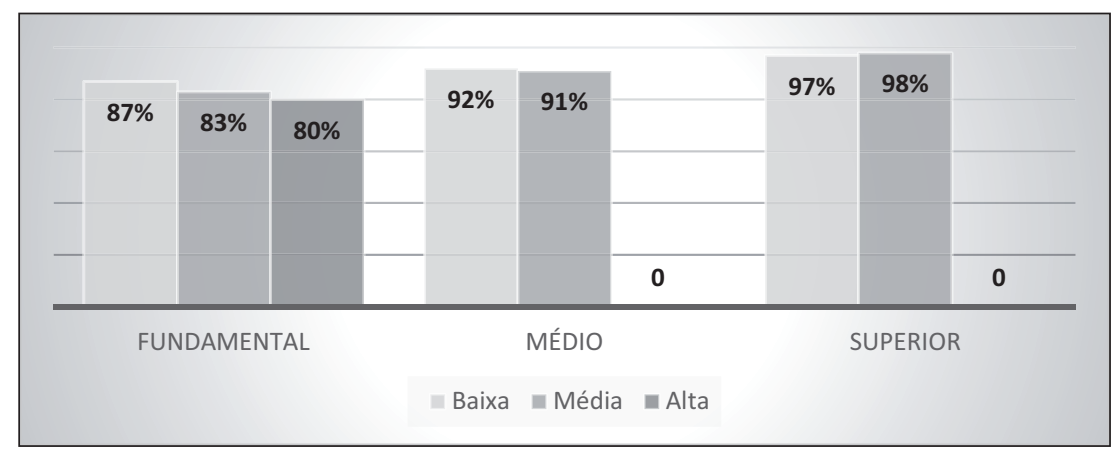

Figura 3 Cruzamento de dados com marca P6: língua(s) de intercomunicaçãox escolaridade no PST

Fonte: Adaptado de Vieira; Silva (2017: 23)

De acordo com as autoras, 
Valendo-se da proposta de Labov (2003) - que propõe a categorização de regras em categóricas (100\% de uma das formas), semicategóricas (95 a 99\% de uma das formas) e variáveis (5-95\% de uma das formas) -, observa-se que os universitários apresentam cerca de $98 \%$ de concordância, enquadrando-se na classificação de uma regra semicategórica. Os falantes de ensino médio e fundamental apresentam variação, com evidente diferença entre eles. É importante destacar que o cruzamento com a variável "língua de intercomunicação" se mostra importante para a compreensão desse quadro: os falantes de ensino fundamental que usam o crioulo em casa são os que mais apresentam ausência de concordância, exatamente ao usarem o Português, fora de casa. (VIEIRA; SILVA, 2017, p. 10)

Em poucas palavras, as evidências encontradas no cruzamento das duas variáveis confirmam que, na sociedade são-tomense, como sinalizado nos trabalhos anteriores, mais anos de escolaridade pressupõem maior contato com a Língua Portuguesa, acarretando índices mais elevados de marcação de número, assim como afirmam Brandão; Vieira (2012):

De fato, o prestígio que recebe o Português em terras são-tomenses e o maior ou menor propósito de dominar essa língua, o que pode se tornar possível graças ao acesso à escolaridade, trazem por consequência o maior ou menor domínio das regras canônicas de concordância. (BRANDÃO; VIEIRA, 2012, p. 1055)

\section{b) Sexo}

Em relação à variável sexo, verifica-se que as mulheres são, de fato, as maiores favorecedoras das marcas (.64), o que se correlaciona com o pressuposto laboviano de que elas tenderiam a ser as propulsoras das variantes de maior prestígio. Os homens, por sua vez, revelam um comportamento de maior uso da variante sem marcas de número (.40 para a concordância).

Tabela 10 Aplicação da marca de P6 segundo o sexo no PST

\begin{tabular}{|c|c|c|c|}
\hline SEXO DO INFORMANTE & OCORRÊNCIAS & PERCENTUAL & PESO RELATIVO \\
\hline Homem & $508 / 579$ & $88 \%$ & .40 \\
\hline Mulher & $445 / 474$ & $94 \%$ & .64 \\
\hline
\end{tabular}

Fonte: Vieira; Silva (2017: 23)

Como se vê, esse resultado reforça os relatos discutidos por Vieira; Bazenga (2015), confirmando as tendências ora encontradas em relação ao sexo do informante: 
[...] quanto maior a inserção da mulher na vida social, econômica e profissional (como parece ser o caso de Copacabana e São Tomé), maior a tendência a se efetivar o uso das marcas de plural, forte sinalizador de detenção da cultura letrada. (VIEIRA; BAZENGA, 2015, p. 52)

\subsection{Variáveis linguísticas}

\section{a) Animacidade}

A variável animacidade confirma a hipótese de que sujeitos com traço [-animado] tendem a influenciar a ausência de uso das marcas. Como a Tabela 11 aponta, sujeitos inanimados desfavorecem a marcação (.22 para concordância), ao passo que os animados a favorecem (.57).

Tabela 11 Aplicação da marca de P6 segundo a animacidade no PST

\begin{tabular}{|c|c|c|c|}
\hline ANIMACIDADE DO SUJEITO & OCORRÊNCIAS & PERCENTUAL & PESO RELATIVO \\
\hline [+ animado] & $816 / 879$ & $93 \%$ & .57 \\
\hline$[-$ animado] & $137 / 174$ & $79 \%$ & .22 \\
\hline
\end{tabular}

Fonte: Vieira; Silva (2017: 24)

Os exemplos a seguir, retirados das entrevistas da amostra PST, confirmam essas tendências:

(18) as pessoas me olhavam com bons olhos (PSTA3H)

(19) e depois eu com essas dificuldades todas, mesmo assim, as dificuldades não acaba”. (PSTA2H)

\section{b) Posição do sujeito}

Quanto à posição do sujeito, confirma-se a tendência, já referida, de que sujeitos em posição anterior ao verbo favorecem a presença de marcas (.54), enquanto em posição posposta ao verbo tendem a induzir a ausência de marcação (apenas .14 para a concordância).

Tabela 12 Aplicação da marca de P6 segundo a posição do sujeito no PST

\begin{tabular}{|c|c|c|c|}
\hline POSIÇÃo Do SUJEITO & OCORRÊNCIAS & PERCENTUAL & PESO RELATIVO \\
\hline Sujeito Anteposto & $633 / 688$ & $92 \%$ & .54 \\
\hline Sujeito Posposto & $38 / 53$ & $72 \%$ & .14 \\
\hline
\end{tabular}

Fonte: Vieira; Silva (2017: 25) 
Os exemplos a seguir demonstram tais tendências: no exemplo (20), o sujeito "as coisas", em posição anteposta ao verbo "corram", propicia a marcação de número padrão, enquanto em (21) o sujeito "aquelas lula grande", em posição posposta ao verbo, provoca a ausência de marca de número no verbo "morre":

(20) espero que as coisas corram bem (PSTB2M)

(21) não é lulinha, morre aquelas lula grande mesmo". (PSTA1H)

\section{c) Paralelismo oracional}

De acordo com a hipótese inicial para a variável paralelismo oracional, sintagmas nominais sujeitos com marcas de número favoreceriam a presença de marcas no verbo, ao passo que a ausência delas no SN levaria à não marcação do verbo. Tal hipótese também foi confirmada na amostra em questão, como os dados revelam. No exemplo (22), o sintagma não marcado "financeira" desfavorece a presença da marca de número no verbo "permitia", enquanto em (23), todas as marcas presentes no SN "os meus filhos" favorecem a marcação plural no verbo "passavam":

(22) as condições financeira não permitia prosseguir (PSTA1H)

(23) os meus filhos passavam no jardins (PSTA1M)

Logo, a presença de marcas no SN favorece a marcação no verbo (.53), enquanto o SN sem marcas acarreta a ausência de concordância do verbo (.16), conforme apresentado na Tabela 13.

Tabela 13 Aplicação da marca de P6 segundo o paralelismo oracional no PST

\begin{tabular}{|c|c|c|c|}
\hline PARALELISMO ORACIONAL & OCORRÊNCIAS & PERCENTUAL & PESO RELATIVO \\
\hline SN com marcas de plural & $625 / 672$ & $93 \%$ & .53 \\
\hline SN sem marcas de plural & $17 / 29$ & $59 \%$ & .16 \\
\hline
\end{tabular}

Fonte: Vieira; Silva (2017: 25)

Por fim, Vieira; Silva (2017) concluem:

Em outras palavras, os padrões de concordância em PST urbano verificados no presente estudo não correspondem exatamente aos verificados para o $\mathrm{PE}$ (com dados semicategóricos em geral) - apesar de este ser o modelo que os são-tomenses supostamente tendem a seguir, por ser a prestigiosa variedade do colonizador -, mas também não chegam a se igualar aos das variedades brasileiras, sobretudo as populares, com índices mais baixos de realização da marca de pluralidade. (VIEIRA; SILVA, 2017, p. 17). 
Resumidamente, as tendências encontradas na amostra analisada demonstram que favorecem a concordância no Português de São Tomé: (i) das variáveis extralinguísticas: os indivíduos com nível superior de escolaridade e as mulheres; (ii) das variáveis linguísticas: os sujeitos animados, antepostos ao verbo e com marcas explícitas de plural. Por outro lado, menos anos de escolaridade, sujeitos inanimados e pospostos, e sintagmas sujeitos sem marcas de plural são os contextos que desfavorecem as marcas de concordância na amostra do PST. Vale lembrar que, conforme mostram os resultados do cruzamento entre os grupos de fatores em questão, a variável relacionada ao uso de línguas crioulas demonstra correlação direta com a escolaridade, indicando que o maior contato com elas pressupõe indicação de menos anos de estudo formal e, consequentemente, de índices mais altos de não concordância.

Ressalte-se que os fatores sociais, ao que tudo indica, mostram-se altamente relevantes para a caracterização das variedades africanas do Português, especialmente as exploradas no presente capítulo (PST e PM), devido ao elevado prestígio associado ao uso de Português, como declaram Vieira; Brandão (2012) sobre o PST:

[...] ao que tudo indica, o valor social que se atribui à não concordância seria compatível com um estereótipo (nos termos de Labov (1972)) ou, na melhor das hipóteses, com um marcador. Por essa razão, o fenômeno variável funciona como nítido identificador do perfil social do usuário da língua. No PST - que configura um caso de variedade do português em formação, com normas objetivas ainda não totalmente definidas e assumidas pelos diferentes grupos de falantes -, sabe-se que dominar a concordância segundo a norma culta que lhe serve de modelo, a do Português Europeu, seria um dos índices de identificação de pleno domínio da Língua Portuguesa. (BRANDÃO; VIEIRA, 2012, p. 1061)

\section{A CONCORDÂNCIA NO PM E NO PST: UMA BREVE COMPARAÇÃO}

Os resultados dos trabalhos revisitados no presente capítulo permitem a verificação de tipos de regra diferentes em relação ao fenômeno da concordância verbal nas variedades estudadas. Enquanto a variedade são-tomense apresenta um comportamento um pouco mais parecido com o das variedades brasileiras urbanas, por atuar dentro dos índices de variação $(90,5 \%)$, a variedade moçambicana sinaliza um desempenho semicategórico $(96,8 \%)$ - nos termos de Labov (2003) - de marcação de número, mais próximo dos valores encontrados no Português Europeu. No entanto, as variáveis sociais, sobretudo no que se refere ao perfil do informante quanto ao emprego das línguas locais ou não, e os contextos qualitativos que atuam sobre a não concordância do PM também o aproximam, em alguma medida, das variedades brasileiras. 
Dessa forma, pode-se compreender que, embora ambas as variedades tenham como modelo de aquisição o Português Europeu, elas apresentam uma realidade linguística que interfere diretamente no uso da norma considerada padrão. Sendo assim, atesta-se, de acordo com os fatores aqui analisados, o afastamento dos índices (semi)categóricos de concordância verificados em amostras do PE, especialmente por conta da sensibilidade aos fatores extralinguísticos como a escolaridade, que não impõe qualquer tipo de restrição quanto ao uso das marcas pelos europeus, e o contato com outras línguas (antes, durante ou após o aprendizado de Língua Portuguesa), além de alguns fatores linguísticos que atuam de forma similar em variedades brasileiras. O quadro a seguir sintetiza as variáveis relevantes para as duas variedades africanas:

Quadro 1 Variáveis selecionadas para a implementação da ausência de concordância de P6 por amostra (PM x PST)

\begin{tabular}{|c|c|}
\hline MOçAMBIQUE (PM) & SÃo TOMÉ E PRÍNCIPE (PST) \\
\hline Língua(s) dominada(s) pelo informante & Escolaridade \\
\hline Posição do sujeito & Animacidade do sujeito \\
\hline Saliência Fônica & Posição do sujeito \\
\hline Escolaridade & Sexo \\
\hline Paralelismo oracional & Paralelismo oracional \\
\hline Tipo de verbo & \\
\hline
\end{tabular}

Fonte: Pissurno (2017); Vieira; Silva (2017)

A partir do Quadro 1, verifica-se que atuam nas duas variedades africanas a escolaridade, a posição do sujeito e o paralelismo oracional, ainda que as duas primeiras variáveis apareçam em ordem diferente. A variedade são-tomense se particulariza em relação à seleção de animacidade do sujeito e sexo do informante, enquanto apenas na moçambicana se observa a atuação das línguas dominadas pelo informante, a saliência fônica e o tipo de verbo 7 .

Em geral, pode-se dizer que as variedades demonstram tendências semelhantes quanto ao uso de línguas além do Português, uma vez que, independentemen-

7 Ressalte-se que Vieira; Silvia (2017) descrevem a interferência entre as variáveis saliência fônica e tipo de verbo no PST (não selecionadas estatisticamente, porém indicando comportamento relevante para a não marcação), que não foram inseridas no presente capítulo por questões de delimitação de espaço. 
te do nível de escolaridade, as duas representam uma realidade de contato entre línguas que atua sobre as regras de marcação plural. No caso da variedade são-tomense, observa-se esse comportamento, principalmente, na frequência média de uso de um crioulo, ao passo que na moçambicana, tal cenário é refletido naqueles que falam fluentemente o Português e uma (ou mais) línguas locais.

Ademais, os dados mostram que, nas duas variedades, é evidente a influência do uso, seja de uma língua local ou de um crioulo, nos valores obtidos e sua relação com o ensino de Português, já que ela é inversamente proporcional ao nível de escolaridade. Em outras palavras, quanto mais anos de escolaridade (ensino médio e superior), maior o contato com o Português considerado formal e, consequentemente, menor interferência das outras línguas, refletindo os índices mais altos de marcação plural nas duas amostras (todos acima dos 90\%). Esse resultado confirma o caráter fundamental da instrução escolar na aprendizagem do Português nas variedades em questão e ainda permite a confirmação da hipótese de que o contato linguístico pode, de fato, afetar os índices de concordância verbal nas variedades de Língua Portuguesa em formação.

Assim, como concluem Vieira; Bazenga (2015) sobre a escolaridade e o uso de línguas:

A correlação entre as referidas variáveis, na qualidade de evidência empírica, favorece a hipótese de que o maior contato linguístico se correlacione à menor realização da marca, hipótese empregada nos estudos que defendem ser a não concordância brasileira, nos níveis e contextos existentes, oriunda da forte situação de contato linguístico entre negros, índios e brancos. (VIEIRA; BAZENGA, 2015, p. 51)

Compreende-se, portanto, que a realidade linguística das variedades africanas deve ser criteriosamente observada por conta da forte realidade multilinguística presente nessas sociedades, em especial na moçambicana, cujo bilinguismo/ multilinguismo tem se mostrado cada vez mais frequente entre os falantes de todas as idades e origens. Em poucas palavras, vale considerar que, em menor ou maior grau, a depender de todos os fatores extralinguísticos relacionados ao uso das línguas em cada sociedade, é imperativo não tratar tais variedades de Português como isentas da influência do multilinguismo, como se elas fossem reproduções do Português Europeu e totalmente distanciadas de qualquer "desvio" associado ao uso de um crioulo ou de uma língua Banto.

\section{CONSIDERAÇÕES FINAIS}

A análise contrastiva entre a variedade são-tomense e a moçambicana do Português aqui realizada revelou diferenças em relação ao estatuto da regra de 
concordância, ao constatar, aparentemente, uma regra variável na primeira - embora com alto índice de realização da concordância - e uma semicategórica na segunda. De toda forma, os condicionamentos que desfavorecem a concordância verbal em ambas as amostras demonstraram que se trata de graus de efetivação de uma regra que pode ser considerada variável nas duas variedades, sobretudo se considerada a complexidade da composição dessas amostras quanto ao uso de Português em uma realidade multilíngue. Assim, o comportamento dos fatores linguísticos - não obstante as diferenças já detalhadas - aproxima, de modo geral, o comportamento das duas variedades e, ao que tudo indica, são os fatores extralinguísticos os que atuam de maneira mais evidente sobre as variedades em questão.

Em relação a esses condicionamentos, evidenciou-se a relevância do nível de escolaridade dos indivíduos, confirmando tendências de que, quanto maior for a escolaridade, maiores serão os índices de favorecimento das marcas. Ao lado dessa condição, o emprego de línguas locais indica que a influência do menor ou maior uso do Português está, de fato, relacionado ao maior grau de instrução formal. O contato mais intenso com outras línguas, aliado à baixa escolaridade, favorece a ausência de marcas de plural nos dados observados. De outro lado, os fatores linguísticos relevantes para ambas as variedades foram a posição do sujeito e o paralelismo oracional, apontando tendências de maior favorecimento das marcas quando os sujeitos estão antepostos ao verbo e possuem marcas explícitas de número.

Por fim, afirma-se que o aprofundamento das hipóteses sobre o estabelecimento de um continnum de marcação de pluralidade nas variedades africanas, à semelhança do proposto em Pissurno (2017), é fundamental. Isto porque os resultados apontados nas pesquisas ora relatadas demonstram que parece mesmo haver posições intermediárias para cada uma dessas variedades, que, devido a seu caráter linguístico particular e as semelhanças em relação à aprendizagem do Português em cada sociedade, estabelecem posições que ora as aproximam e ora as afastam de seu suposto modelo de aquisição - o Português Europeu. As respostas finais para a caracterização de cada variedade dependem, sem dúvida, do maior conhecimento da complexa realidade sociolinguística das variedades são-tomense e moçambicana, o que impõe continuar nos caminhos de investigação ora trilhados.

\section{REFERÊNCIAS}

ANTÓNIO, T. Estratégias de ensino da concordância verbal em número à população universitária moçambicana. 2001. Dissertação (Mestrado em Letras e Ciências Sociais) - Faculdade de Letras, Universidade Eduardo Mondlane - UEM, Moçambique. 
BAVO, N. Prática de estruturas: Concordância verbal em número. 2011. Disponível em: $<$ www.catedraportugues.uem.mz/lib/docs/N.Bavo_fINAL20Abril2012.pdf<. Acesso em: 17 de dezembro de 2015.

BRANDÃO, S. F. O cancelamento da marca de número nominal na variedade urbana não standard do Português de São Tomé. Documentos del XVI Congreso Internacional de la ALFAL. CD-Rom. Alcalá de Henares: ALFAL, 2011.

BRANDÃO, S. F.; VIEIRA, S. R. A concordância verbal e nominal no português do Brasil e no português de São Tomé: uma abordagem sociolinguística. Papia, São Paulo, v. 22, n. 1, p. 7-40, 2012a.

BRANDÃO, S. F.; VIEIRA, S. R. Concordância nominal e verbal: contribuições para o debate sobre o estatuto da variação em três variedades urbanas do português. Alfa, São Paulo, v. 56, n. 3, p. 1035-1064, 2012b.

FIGUEIREDO, C. F. G. A concordância variável no sintagma nominal plural do Português restruturado de Almoxarife (São Tomé). Revista de Crioulos de Base Lexical Portuguesa e Espanhola, Lisboa, v. 1, n 1, p. 28-55, 2009.

FIGUEIREDO, C. F. G. A concordância plural variável no sintagma nominal do português reestruturado da comunidade de Almoxarife, São Tomé (Desenvolvimento das regras de concordância variáveis no processo de transmissão-aquisição geracional). 2010 . Tese (Doutorado em Linguística) - Faculdade de Ciências Sociais e Humanas, Universidade de Macau - Macau, 2010.

GANDRA, A. S. A concordância verbal no português europeu rural. In: OLIVEIRA, K.; SOUZA, H. C.; GOMES, L. (Org.). Novos tons de Rosa... para Rosa Virgínia Mattos e Silva. Salvador: EDUFBA, 2009. p. 142-161.

GONÇALVES, P. Tipologia de erros do Português Oral de Maputo: um primeiro diagnóstico. In: GONÇALVES, P.; STROUD, C. (Org.). Panorama do Português oral de Maputo, v. II - A construção de um Banco de "Erros". INDE - Cadernos de Pesquisa n. 24. Maputo: Moçambique, 1997.

GONÇALVES, P. Aspectos morfossintáticos da gramática do Português de Moçambique: A concordância nominal e verbal / Morphosyntactic aspects of the grammar of mozambican portuguese: Nominal and verbal agreement. Cuadernos de la ALFAL, v. 7, p. 9-16, 2015.

HAGEMEIJER, T. As línguas de São Tomé e Príncipe. Revista de Crioulos de Base Lexical Portuguesa e Espanhola, Lisboa, v. 1, n. 1, p. 1-27, 2009.

JON-AND, A. Variação, contato e mudança linguística em Moçambique e Cabo Verde. A concordância variável de número em sintagmas nominais do português. 2011. Tese (Doutorado) - Department of Spanish, Portuguese and Latin American Studies, Stockholm University - Suécia, 2011.

JUSTINO, V. Concordância verbal em número: da descrição linguística à avaliação no contexto de ensino-aprendizagem. In: BASTOS, M.; MARQUES, J.; MONTEIRO, A.; SIOPA, C. (Org.). Ensinar a lingua portuguesa em Moçambique: Desafios, possibilida- 
des e constrangimentos. Textos selecionados das VII Jornadas da Língua Portuguesa. Porto: Porto Editora, 2015a. p. 166-186

LABOV, W. Sociolinguistic patterns. Philadelphia: University of Pennsylvania Press, 1972.

LABOV, W. Principles of linguistic change. Oxford, Cambridge: Blackwell, 1994. v. 1.

LABOV, W. Some sociolinguistic principles. In: PAULSTON, C. B.; TUCKER, G. R. (Org.). Sociolinguistics. The essential readings. Oxford/New York: B. Blackwell, 2003. p. 234-250.

LUCCHESI, D.; BAXTER, A.; SILVA, Jorge A. A. da. A concordância verbal. In: LUCCHESI, D.; BAXTER, A.; RIBEIRO, I. (Org.). O Português afro-brasileiro. Salvador: Edufba, 2009. p. 331-371.

MONGUILHOTT, I. O. S. Estudo sincrônico e diacrônico da concordância verbal de $3^{a}$ pessoa do plural no PB e no PE. 2009. Tese (Doutorado em Linguística e Língua Portuguesa) - Programa de Pós-graduação em Linguística, Universidade Federal de Santa Catarina - UFSC, Florianópolis, 2009.

MONTE, A. Concordância verbal e variação: um estudo descritivo-comparativo do Português Brasileiro e do Português Europeu. 2012. Tese (Doutorado em Linguística e Língua Portuguesa) - Programa de Pós-graduação em Linguística e Língua Portuguesa, Universidade Estadual Paulista “Júlio Mesquita Filho" - UNESP, São José do Rio Preto, 2012.

NHONGO, N. A concordância verbal em número no discurso escrito de estudantes universitários moçambicanos. 2005. Tese (Licenciatura) - Faculdade de Letras, Universidade Eduardo Mondlane - UEM, Moçambique, 2005.

PETTER, M. M. T. Ampliando o continuum afro-brasileiro de Português. Papia, São Paulo, v. 25, n. 2, p. 305-317, 2015.

PISSURNO, K. C. S. A concordância verbal de terceira pessoa do plural na variedade moçambicana do Português: uma abordagem sociolinguística. 2017. Dissertação (Mestrado em Letras Vernáculas) - Programa de Pós-graduação em Letras Vernáculas, Universidade Federal do Rio de Janeiro - UFRJ, Rio de Janeiro, 2017.

ROMAINE, S. Introduction to the study of Bilingualism. In: ROMAINE, S. (Org.). Bilingualism. 2. ed. Oxford: Blackwell, 1995. p. 1-22.

RUBIO, C. F. Padrões de concordância verbal e de alternância pronominal no português brasileiro e europeu: estudo sociolinguístico comparativo. Tese (Doutorado em Estudos Linguísticos) - Instituto de Biociências, Letras e Ciências Exatas, Universidade Estadual Paulista “Júlio Mesquita Filho” - UNESP. São José do Rio Preto, 2012.

SCHERRE, M. M. P.; NARO, A. J. Duas dimensões do paralelismo verbal no Português popular do Brasil. DELTA, São Paulo, v. 9, n. 1, p. 1-14, 1993.

SCHERRE, M. M. P.; NARO, A. J. A concordância de número no Português do Brasil: um caso típico de variação inerente. In: HORA, D. (Org.). Diversidade linguística no Brasil. João Pessoa: Ideia, 1997. p. 93-114. 
SCHERRE, M. M. P.; NARO, A. J. Mudança sem mudança: a concordância de número no português brasileiro. SCRIPTA, Minas Gerais, v. 9, n. 18, p. 107-129, 2006

SCHERRE, M. M. P.; NARO, A. J.; CARDOSO, C. R. O papel do tipo de verbo na concordância verbal no português brasileiro. DELTA, São Paulo, v. especial, n 23, p. 238-317, 2007.

VAREJÃO, F. Variação em estruturas de concordância verbal e em estratégias de relativização no português europeu popular. 2006. Dissertação (Mestrado em Letras Vernáculas) - Programa de Pós-graduação em Letras Vernáculas, Universidade Federal do Rio de Janeiro - UFRJ, Rio de Janeiro, 2006.

VIEIRA, S. R. O estatuto da regra variável e o fenômeno da concordância verbal em variedades do Português. Documentos del XVI Congreso Internacional de la ALFAL. CD-Rom. Alcalá de Henares: ALFAL, 2011.

VIEIRA, S. R.; BAZENGA, A. Patterns of third person verbal agreement. Journal of Portuguese Linguistics, Lisboa, v. 12, n. 2, p. 7-50, 2013.

VIEIRA, S. R.; BAZENGA, A. A concordância da terceira pessoa plural: padrões em variedades do Português. 2013. In: VIEIRA, S. R. (Org.). A concordância em variedades do Português: a interface Fonética-Morfossintaxe. Rio de Janeiro: Vermelho Marinho, 2015. p. 29-75.

VIEIRA, S. R.; BRANDÃO, S. F. Tipologia das regras linguísticas e estatuto das variedades/línguas: a concordância em português. Linguística, Rio de Janeiro, v. 30, n. 2, p. 81-112, 2014.

VIEIRA, S. R.; SILVA, K. C. Estudo sociolinguístico da concordância verbal de $3^{a}$ pessoa do plural no Português de São Tomé e Príncipe. Revista Letrônica, Rio Grande do Sul, v. 10, n. 1, p. 18-29, 2017.

WEINREICH, U.; LABOV, W.; HERZOG, M. Empirical foundations for theory of linguistic change. In: LEHMANN, W.; MALKIEL, Y. (Org.). Directions for Historical Linguistics. Austin: University of Texas Press, 1968. p. 97-195. 
